\title{
Innovative Potential: The Main Drivers of Digital Transformation
}

\author{
Irina Davydenko \\ Economic Security and Financial Monitoring Department \\ Voronezh state university of engineering technologies \\ Voronezh, Russia \\ Elena Kolesnikova \\ Economic Security and Financial Monitoring Department \\ Voronezh state university of engineering technologies \\ Voronezh, Russia
}

\author{
Olga Kolomytseva \\ Economic Security and Financial Monitoring Department \\ Voronezh state university of engineering technologies \\ Voronezh, Russia \\ Viktoriia Grigorieva \\ Economic Security and Financial Monitoring Department \\ Voronezh state university of engineering technologies \\ Voronezh, Russia
}

\author{
Elena Reznikova \\ Economic Security and Financial Monitoring Department \\ Voronezh state university of engineering technologies \\ Voronezh, Russia \\ elenardrug@mail.ru
}

\begin{abstract}
Digitalization is currently a topic of great interest and is a source of transformation in various fields of activity. Numerous new technologies in the field of the Internet of Things, virtual and augmented reality, big data and many others offer great opportunities for a radical update of the business model. Many startups and well-known companies have already demonstrated how digitalization can revolutionize processes and transform entire markets with new experiences. This article discusses key drivers that play an important role in the digital transformation of a company's innovation potential. It also shows that, despite the opportunities that digitalization of innovation potential offers, there are still issues that need to be addressed.
\end{abstract}

Keywords: innovative potential, innovation environment, digitalization, digital transformation

\section{INTRODUCTION}

It is impossible to overestimate the role of innovation in the modern economy. They are a key element in the formation and transformation of technological waves and the development of socio-economic relations. Innovation involves the emergence of new and a combination of old and new ideas and knowledge. However, despite the fact that innovation is based on the use of new ideas and inventions, they cannot be identical.

C. Freeman (1982) makes a clear distinction between them when he notes: "an invention is an idea, sketch, or model for a new or improved device, product, process, or system", while "innovation in an economic sense is carried out only with the first business transaction involving a new product, process, system or device".

The Organization for Economic Co-operation and Development expanded this statement by proposing the wording - "an innovation consists of all the scientific, technical, commercial and financial steps necessary for the successful development and marketing of new or improved industrial products, commercial use of new or improved processes or equipment, or implementation a new approach to social services".

Innovation research by foreign scientists such as Freeman (1987); Lundvall (1992); Nelson (1993) led to the formation of two important concepts:

- the company's ability to innovate depends on the infrastructure of a country or region;

- companies have various opportunities for innovation.

Thus, the ability to innovate can be considered as the potential of this company to create an innovative product. There are various approaches in determining the essence of the concept of "innovative potential".

From our point of view, innovative potential is a comprehensive characteristic of the state of the economic system, in which there is a direct opportunity to implement and participate in transformations of an innovative nature. It is 
obvious that the changes caused by the digitalization processes in the economy should also lead to the evolution of individual economic processes. In particular, the emergence of new financing mechanisms and resource support can change the nature and structure of the innovative potential of an economic entity.

Recent decades have led to a radical change in the communication and technology used by humans. Letters have been replaced by e-mails, and phone calls have been supplemented by chats and text messages. The advent of the Internet has changed our lives more than any other development in any age. What it used to take many years to communicate is now just a moment, and this has allowed us to keep pace with the rapid development of today's life. All this has led to the fact that the share of active users of the Internet and mobile devices has exceeded more than half of the world's population (Fig.1).

On the other hand, the advent of big data processing technologies, artificial intelligence, blockchain, virtual and augmented reality and other has made businesses face the challenge of meeting the new digital reality. Digital technologies have caused a business desire to remake a process to become more efficient or effective.

The main goal is not to reproduce an exiting service in a digital form, but to use the transformation process for a qualitative fundamental change of business. This is confirmed by the fact that global spending on digital transformation continues to grow at an average annual rate of $16-18 \%$.

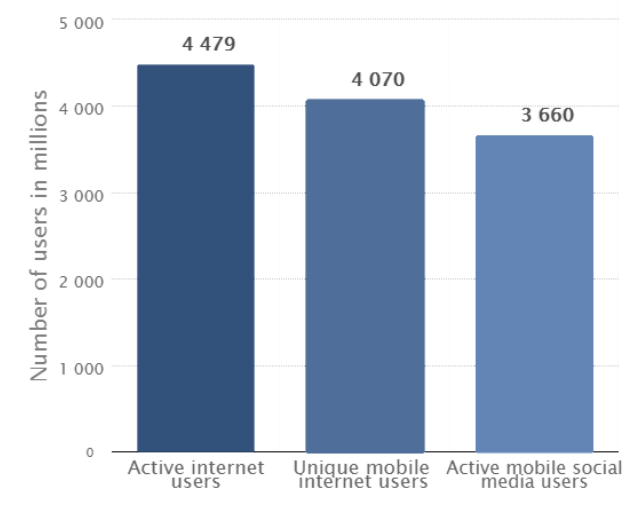

Fig. 1. Global digital population 2019 (in millions)

According to the results of 2017 , their volume exceeded $\$ 1.3$ trillion, and by 2021 it is forecasted to grow up to $\$ 2.1$ trillion [1].

\section{DISCUSSION}

In our opinion, we would like to highlight the digitalization key drivers of the company's innovative potential.

\section{A. Digital personalization}

Digital customer personalization is a key driver for transforming the company's innovative potential. This enables companies to create a digital ecosystem based on the development and offering of personalized products and services. This is made possible by digital tools for processing large amounts of customer data. It gives the company an understanding of what customers really want and are willing to pay for. In the future, this may allow for the availability of offers and payment models based on individual consumption levels.

\section{B. Goods servitization}

The innovative success of a company is based on the ability not only to create, but also to sell innovative products or services. In this regard, the digitalization of goods and services allows for the creation of new combinations of features and properties that were not previously inherent to them. This blurs the traditional view and allows the company to offer a service as a product and a product as a service.

The service business model, which allows manufacturers to receive additional income from providing the customer with a part of the equipment as a service, requires the use of modern information technologies of high complexity. This is the reason for the change in the perception of the innovative potential of the company, which is expressed in the digital transformation of the process of creating and promoting an innovative product with the involvement of consumers, instead of based solely on R\&D and the traditional chain of product promotion.

For example, office equipment manufacturer Xerox has applied the Remote Print Service business model. Payment for the service is made only for the actual number of printed copies made by the customer. The Xerox business model includes the provision, replacement and maintenance of office equipment.

\section{Processes\&structures changes}

Servitization, forecasting and applying Internet of Things (IoT) data in a company's innovative business processes can be used to improve service management or to understand how customers use purchased products. This allows the company to move from traditional product competition to a competition model "customer as a service consumer".

Shifting the cost structure of an innovative company to operating expenses instead of capital ones is aimed at finding non-standard approaches to generate additional income and transition to the business model of "product as a service". For example, the North American market (Frost \& Sullivan) is expected to generate $\$ 4$ billion in revenues from calibration and repair services alone in 2022.

There is, meanwhile, plenty of evidence that digitalization is revolutionizing the transformation of business processes, markets and customer experience. The company's innovation potential is an excellent area for realizing the benefits of digitalization, but requires appropriate structural and functional changes in the company (Fig.2).

Structural changes should be aimed at increasing employee engagement and providing a customer-like user experience. One option is to improve the digital workspace. The digital 
workspace increases efficiency and raises employee engagement and agility. Also it enable employees to exploits consumer-oriented styles and technologies. [2; 3].

Another option is to integrate $\mathrm{R} \& \mathrm{D}$ into open innovation. Research activities are carried out in such a way as to conduct research, design, development and maintenance of new products and services with ongoing activities in a wholistic business operation at the same time. Digitalization processes blur the distinction between open innovation and $R \& D$, allowing soft open innovation resources to be absorbed from the external digital environment in order to transform routine or periodic activities leading to transforming these activities into activities that lead to significant improvement $[4 ; 5 ; 6]$.

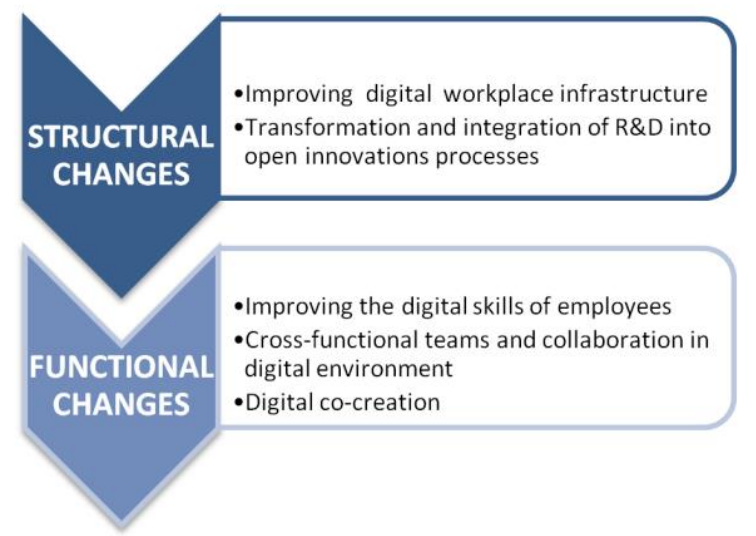

Fig. 2. Changes for digital transformation

In addition to structural changes, there are changes needed in functional. One option is to improve digital skills of employees. Digital skills of employees and their integration into the traditional management knowledge system are necessary for the implementation of digital models of innovative potential development. Its importance is reflected not only in the level of technical training, but also in the formation of a digital mentality [7; 8; 9].

Another option is implementing cross-functional teams that can address specific problems, and design and implement solutions, help both to move digital transformation forward and to change mentality. Collaborative behaviors are adopted more as a result of intrinsic need and an intrinsicallymotivated process of experimentation and learning, and foster high levels of creativity and innovation in teams responsible for managing other complex tasks, and delivering highly creative solutions $[10 ; 11]$.

Also, digital co-creation approach brings together an evolving ecosystem of inputs and insights - from customers, end users, research bodies, and beyond. It possible to exploit the enormous potential of Artificial Intelligence (AI), the Internet of Things (IoT), hybrid cloud and security [12-16; $19 ; 20]$.

\section{CONCLUSION}

According to the authors, the key factors of digital transformation of the company's innovative potential were highlighted. Their joint implementation will change the traditional perception of the innovative potential. In our opinion, digitalization can serve as a practical basis for the transformation of innovative potential from a separate business process to a system-forming factor of the company's development.

Despite the fact that digital transformation of innovative potential will radically change the economic and innovative landscape, a number of issues remain unresolved. For example, the participation of consumers and employees in the joint creation of innovative products and services is not regulated by the legal aspects of their interaction. The growing gap between the level of innovation development of different countries, which depends not only on the level of economic prosperity but also on the ability to actively participate in the process of digitalization and use of intellectual property, increases the risk of falling into the "trap of increasing innovation and technological gap", which creates new global risks. [17; 18].

\section{REFERENCES}

[1] M. Popova, "Income in numbers: how companies are reshaping business processes," Digital economy, vol. 4(9), 2018.

[2] M. Attaran, S. Attaran, D. Kirkland, "The need for digital workplace: increasing workforce productivity in the information age," International Journal of Enterprise Information Systems, vol. 15(1), 2019, pp. 1-23.

[3] P. Miller, "The Digital Workplace: How Technology Is Liberating Work," Dog Ear Publishing, 2012.

[4] Y. Tou, C. Watanabe, K. Moriya, V. Vurpillat, P. Neittaanmäki, “A new concept of R\& D in neo open innovation: transformation of R\&D triggered by Amazon,” Int. J. Manag. Inf. Technol, vol. 11(1), 2019, pp. 17-35.

[5] Y. Tou, and et al, "Neo open innovation in the digital economy: harnessing soft innovation resources," International Journal of Managing Information Technology (IJMIT), vol. 10, 2018.

[6] Y. Tou, and et al, "The transformation of R\&D into neo open innovation-a new concept in R\&D endeavor triggered by amazon," Technology in Society, vol. 58, 2019, p. 101141.

[7] D. Leahy, D.Wilson, "Digital skills for employment," In IFIP Conference on Information Technology in Educational Management. Springer, Berlin, Heidelberg, 2014, pp. 178-189.

[8] "Skills for a Digital World", Policy Brief on The Future of Work, OECD Publishing, Paris, 2016.

[9] Yu.A. Salikov, I.V. Logunova, I.V. Kablashova, "Trends in human resource management in the digital economy," Vestnik VGUIT, vol. 81(2), 2019, pp. 393-399.

[10] "Digital Strategy Environmental Scan," Athenaeum21 Consulting for Concordia University, June 2018.

[11] A.R. Jassawalla, H.C. Sashittal, "Building collaborative cross-functional new product teams," Academy of Management Perspectives, vol. 13(3), 1999, pp. 50-63.

[12] S. Lee, D. Olson, S. Trimi, "Co-innovation: convergenomics, collaboration, and co-creation for organizational values," Management Decision, vol. 50(5), 2012, pp. 817-831.

[13] D. Romero, M. Arturo, "Collaborative networked organisations and customer communities: value co-creation and co-innovation in the networking era," Production Planning \& Control, vol. 22(5-6), 2011, pp. $447-472$.

[14] S. Kumar, K. Megha, "Co-creation a new method of building brand loyalty \& innovation," International Journal of Management (IJM), vol. 9(6), 2018. 
[18] L.N. Nekhorosheva, Modern global challenges and threats: "new normality" and "turbulence of the economy, Doctoral dissertation, Belarusian state University of Economics, 2016.

[19] C.K. Prahalad, V. Ramaswamy, "Co-opting customer competence," Harvard business review, vol. 78(1), 2000, pp. 79-90.

[20] T.I. Ovchinnikova, I.A. Davydenko, "Increasing employee income: an innovative approach based on a combination of factors of production and consumption," Vestnik VGUIT, vol. 81(3), 2019, pp. 261-266. 